\title{
Analisis manajemen event Reyog Jazz sebagai salah satu strategi komunikasi pemasaran budaya dan wisata Kabupaten Ponorogo
}

\author{
Fatika Bella Ayunda ${ }^{a, 1, *}$, Krisna Megantari ${ }^{\text {b,2 }}$ \\ ${ }^{a}$ Universitas Muhammadiyah Ponorogo \\ ${ }^{1}$ fatikabella10@gmail.com*; ${ }^{2}$ megantarikrisna@gmail.com; \\ * corresponding author
}

Article history

Received 06-01-2021

Revised 18-01-2021

Accepted 02-02-2021

Keywords

Manajemen Event

Strategi

Pemasaran

Reyog Jaz Ponorogo

\begin{abstract}
Pemerintah Kabupaten Ponorogo sedang melakukan upaya untuk memasarkan atau mempromosikan potensi yang ada di Ponorogo agar dikenal oleh masyarakat dari lokal, nasional ataupun internasional. Salah satunya yakni dengan menggunakan event, seperti event Reyog Jazz yang dibuat sebagai strategi komunikasi pemasaran budaya dan wisata Kabupaten Ponorogo. Maka dari itu untuk melaksanakan event Reyog Jazz dibutuhkan pengorganisasian dari awal sampai akhir yang disebut dengan manajemen event. Penelitian ini menggunakan metode deskriptif kualitatif, dimana permasalahan dijelaskan secara sistematis dan berdasarkan data yang diperoleh dengan melalui observasi langsung ataupun wawancara kepada pihak-pihak yang dirasa kompeten untuk menjawab permasalahan yang ada, seperti Bapak Agus Setiawan Basuni selaku Founder WartaJazz, Ibu Farida Nuraini, S.Sos.,MM dan Bapak Franky Andrias.M selaku Dinas Pariwisata Kabupaten Ponorogo, Volunteer, serta beberapa pengunjung yang mentonton event Reyog Jazz. Untuk menjawab permasalahan yang ada maka digunakan teori manajemen event milik Goldblatt yang terdiri dari Research, Design, Planning, Coordination, Evaluation. Hasil dari penelitian ini menunjukan bagaimana tim Reyog Jazz merencanakan event sampai dengan penerapannya. Dan jika dilihat, tim Reyog Jazz sudah menerapkan manajemen event dengan cukup baik meskipun pada implementasinya masih terdapat beberapa evaluasi.
\end{abstract}

This is an open access article under the CC-BY-SA license.

\section{Introduction}

Promosi pada dasarnya ialah sebuah wujud dari komunikasi pemasaran.Yang mana aktifitas disini berhubungan dengan bagaimana menyebarkan informasi, membujuk atau mengajak, serta dapat menjadikan daya tarik bagi masyarakat. Promosi sendiri sudah sering dilakukan dengan berbagai cara atau media. Misalnya dengan sosial media, word to mouth, ataupun dengan media event marketing ataupun special event.Pelaksanaan event sudah tidak asing lagi di Indonesia.Baik skala kecil ataupun besar, di lingkup daerah ataupun event kenegaraan. Sebab saat ini event dapat dikatakan menjadi salah satu cara atau instrumen yang efektif baik untuk meningkatkan pendapatan, menarik perhatian khalayak, ataupun sebagai salah satu strategi mempromosikan budaya atau wisata didaerah tertentu. Selain itu dalam buku Event Management (Any, 2009) menyebutkan kunci utama event adalah pengunjung dapat mengetahui manfaat apa yang akan didapat melalui sebuah event yang sedang dijalankan, yakni dengan bagaimana event itu dibuat dan dikemas. Seperti yang dilakukan oleh Pemerintah Kabupaten Ponorogo yang menggunakan event sebagai salah satu strategi untuk mengenalkan atau mempromosikan potensi yang ada di Ponorogo, yakni melalui event Reyog Jazz (Lotan, 2019). 
Event Reyog Jazz sendiri berangkat dari hasil diskusi tiga founder WartaJazz yakni Agus Setiawan Basuni, Yusuf Koen, dan Syaefudin Dimyati untuk mewujudkan impian Bupati Ponorogo mempromosikan atau mengenalkan potensi Ponorogo dikalangan lokal, nasional maupun mancanegara(Jandevi, 2019a), maka tercetuslah penggagasan event atau festival yang mengangkat musik Jazz yang tentunya banyak digemari banyak kalangan yang diberi nama Reyog Jazz. Dimana event ini menjadikan sebuah alasan untuk mengenalkan kembali nama Ponorogo yang tidak hanya dikenal dengan Reog nya tetapi juga dengan potensi daerahnya. Sebagai contoh orang pasti mengetahui nama kota Ponorogo. Apalagi ketika berbicara tentang Reog, orang pasti akan langsung menebak itu dari Ponorogo. Tetapi yang menjadi masalah ialah ketika ditanya dimana letak Ponorogo, dan bagaimana untuk berkunjung ke Ponorogo, maka belum tentu semua orang akan tahu. Maka disitulah Event Reyog Jazz ini digagas agar menjadi sarana yang dapat menjadi penghubung kepada wisatawan yang ingin berkunjung ke Ponorogo.Apalagi di Ponorogo ini tidak hanya menawarkan wisata alam, tetapi juga wisata kuliner, budaya, dan juga wisata yang berhubungan dengan sejarah dan juga agama. Event Reyog Jazz merupakan kerjasama antara Pemerintah Kabupaten Ponorogo dengan Warta Jazz yang merupakan ekosistem jazz di Indonesia dengan pengalamannya lebih dari 17 tahun mendukung dan mengembangkan berbagai kegiatan jazz termasuk festival. WartaJazz juga memiliki kepedulian pada pengembangan generasi muda terhadap musik, serta sering kali melakukan pemberdayaan komunitas dan ikut mempromosikan talentatalenta yang dimiliki Indonesia sampai ke mancanegara (Sintawati, 2019). Dengan adanya tujuan berupa mengenalkan potensi yang dimiliki Ponorogo khususnya budaya dan wisata melalui sebuah event, maka dari itu perlu dipikirkan secara matang bagaimana kemasan event yang harus dibuat agar nantinya tujuan diselenggarakannya event Reyog Jazz ini tidak serta merta hanya sebagai acara hiburan melainkan sebagai ajang promosi budaya dan wisata kabupaten Ponorogo. Serta untuk merealisasikan event tersebut dibutuhkan pengorganisasian yang baik dari awal sampai akhir penyelenggaraan yang disebut dengan manajemen event (Putra \& Smolek, 2020).

Berdasarkan permasalahan yang ada, peneliti maka dari itu dirumuskan sebuah permasalahan yakni, bagaimana manajemen event yang dilakukan oleh tim pada event Reyog Jazz, selain itu aktivitas apa yang dilakukan pada event Reyog Jazz sebagai wujud strategi komunikasi pemasaran budaya dan wisata Kabupaten Ponorogo. Dan yang terakhir adalah apa saja yang menjadi kendala tim pada saat pembuatan event Reyog Jazz ini. Dimana nantinya melalui penelitian ini dapat menjawab permasalahan yang ada sehingga memberikan manfaat baik akademis maupun manfaat praktis.

\section{Theorotocal Framework}

a) Strategi Komunikasi Pemasaran

Menurut (Prisgunanto, 2006) komunikasi pemasaran ialah semua hal yang ada pada marketing mix yang melibatkan komunikasi antar instansi atau perusahaan dan target audience elemen-elemen pada segala bentuknya ditujukan untuk performance marketing. Wujud dari komunikasi pemasaran itu sendiri dapat berupa promosi.Karena seperti yang diungkapkan (Tjiptono, 2001) promosi pada dasarnya adalah suatu komunikasi pemasaran, artinya sebuah aktifitas pemasaran dengan tujuan untuk menyebarkan informasi, mempengaruhi/membujuk, dan atau mengingatkan pasar atas perusahaan dan produknya agar dapat diterima, membeli dan loyal pada produk yang ditawarkan. . Kotler dan Armstrong dalam (Hedynata \& Radianto, 2016) mendefinisikan bauran promosi (promotion mix) sebagai perpaduan alat-alat promosi yang biasa digunakan perusahaan untuk mengkomunikasikan value secara persuasif serta membangunhubungan kepada customers. Bauran promosi (promotional mix) terdiri dari 8 model yakni Pertama, Iklan (Advertising)merupakan bentuk terbayar yang mewakili baik nonpersonal dan promosi ide, barang atau jasa melalui sponsor yang jelas melalui media cetak, media penyiaran, media jaringan, dan media elektronik), dan media pameran. Kedua, Promosi Penjualan (Sales Promotion) (Fadillah, 2014a), merupakan sebuah insentif jangka pendek yang berguna untuk mendorong pembelian produk atau jasa termasuk promosi konsumen, promosi perdagangan, dan bisnis promosi tenaga penjualan. Ketiga, Acara dan Pengalaman (Even and Experiences)merupakan kegiatan dan program yang disponsori perusahaan, dirancang untuk menciptakan interaksi dengan konsumen, termasuk seni olahraga, hiburan, dan menyebabkan acara atau kegiatan tersebut menjadi kurang formal. Keempat,Hubungan Masyarakat dan Publisitas (Public Relations and Publicity), merupakan program yang diarahkan secara internal

Fatika Bella Ayunda (Analisis manajemen event Reyog Jazz sebagai salah satu strategi komunikasi pemasaran budaya dan wisata Kabupaten Ponorogo) 
kepada karyawan dari perusahaan atau konsumen, perusahaan lain, pemerintah, dan media untuk mempromosikan, membangun hubungan antar perusahaan dengan publik, serta membangun citra perusahaan.Kelima, Penjualan Personal (Personal Selling) merupakan interaksi tatap muka yang dilakukan oleh perusahaan dengan satu atau lebih pembeli untuk tujuan melakukan pertemuan penjualan, presentasi pribadi, menjawab pertanyaan, pengadaan pesanan, membuat penjualan, dan hubungan pelanggan. Keenam, Pemasaran Langsung (Direct Marketing) merupakan penggunaan surat, telepon, fax, e-mail, atau internet untuk berkomunikasi atau berhubungan secara langsung dengan meminta respon melalui dialog dari pelanggan dan prospek tertentu. Ketujuh, Pemasaran Interaktif (Interactive Online Marketing)adalah kegiatan dan program online yang dirancang untuk melibatkan pelanggan atau prospek dan secara langsung atau tidak langsung meningkatkan kesadaran memperbaiki citra, atau menciptakan penjualan produk dan jasa. Dan terakhir, Pemasaran dari mulut ke mulut (Word of Mouth Marketing) merupakan komunikasi lisan, tertulis, dan elektronik antar masyarakat yang berhubungan dengan keunggulan atau pengalaman membeli atau menggunakan produk atau jasa tersebut (Nurislamia \& Asriya, 2019).

\section{b) Komunikasi Persuasif}

Komunikasi persuasif didefinisikan sebagai suatu proses untuk mempengaruhi seseorang yakni pendapat, sikap dan juga tindakan dengan menggunakan manipulasi psikologis sehingga orang tersebut bertindak seperti atas kehendaknya sendiri (Kriyantono, 2012). Proses pengkomunikasian tersebut nantinya akan menciptakan sebuah efek kepada seseorang yakni, Kognitif yang berhubungan dengan pikiran atau nalar seseorang, sehingga khalayak yang semula tidak tahu, yang semula tidak mengerti, yang tadinya bingung menjadi jelas. Kedua afektif yang berkaitan dengan perasaan seseorang, dimana timbulnya perasaan suka, penasaran, kecewa, dll.Ketiga konatif berupa Efek yang tidak langsung timbul pada seseorang.Tetapi didahului oleh efek kognitif dan afektif.Dan selanjutnya timbul lah minat seseorang untuk membeli, berkunjung, dll (Effendy, 2007).

\section{c) Event}

Event didefinisikan sebagai sebuah kegiatan yang dilakukan untuk memperingati hal-hal tertentu di sepanjang hidup manusia baik individu atau kelompok yang saling terikat adat, budaya, tradisi ataupun agama dan diselenggarakan dengan tujuan dan waktu tertentu serta melibatkan lingkungan masyarakat (Any, 2009). Salah satu tujuan event itu sendiri menurut (Pudjiastuti, 2010) adalah untuk mempromosikan produk atau sebuah perusahaan agar lebih dikenal di khalayak. Tujuan ini akan lebih maksimal ketika ada liputan dari media massa sehingga timbul publisitas bagi produk atau perusahaan yang seang dipromosikan. Wilayah event sampai saat ini terus berkembang seiring berjalannya waktu, hingga merambah ke dunia bisnis yang sering disebut dengan EO (Event Organizing) sebagai jasa penyelenggara event.

\section{d) Budaya}

Menurut Wiranata dalam (Prayogi \& Danial, 2016) menyimpulkan bahwa budaya merupakan : Bahwa kebudayaan yang terdapat antara umat manusia itu sangat beraneka ragam. Bahwa kebudayaan itu didapat dan diteruskan secarasosial melalui proses pembelajaran. Bahwa kebudayaan itu terjabarkan dari komponen biologis, sosiologis, dan psikologis dari eksistensi manusia.Bahwa kebudayaan itu berstruktur. Bahwa kebudayaan itu memuat beberapa aspek Bahwa kebudayaan itu bersifat dinamis Bahwa nilai dalam kebudayaan itu bersifat relatif. Selain itu, budaya itu netral dalam arti tidk normative : tidak ada budaya yang lebih tinggi ataupun budaya yang lebih rendah, tidak ada budaya yang benar dan juga budaya yang salah. Tidak ada budaya miskin tetapi ada budaya kemiskinan (Ndraha, 2005)

\section{e) Pariwisata}

Pariwisata merupakan sebuah elemen kuat yang dimiliki Indonesia. Pariwisata menjadi andalan sumber devisa karena Indonesia memiliki banyak keanekaragaman khususnya pada bidang pariwisata yang dapat dikembangkan. Menurut Undang-undang nomor 9 tahun 1990 dalam (Soedarso, Nurif, \& Windiani, 2014) tentang kepariwisataan, pariwisata diartikan sebagai segala sesuatu yang berhubungan dengan wisata, termasuk pengusahaan obyek dan daya tarik wisata serta usaha-usaha yang terkait dibidang tersebut. Pariwisata tidak hanya terfokus pada tujuan-tujuan yang berhubungan dengan alam, tetapi religi, sosial dan sejarah juga dapat dikatgorikan sebagai wisata. Contohnya tempat bersejarah, masjid bersejarah, dll. 


\section{f) Event Sebagai Strategi Promosi}

Mengutip pendapat dari Dorothy I.Doty (1990) dalam (Pudjiastuti, 2010) menyebutkan, "special event is an effective tools of publicity to keep the name of your company, product or service before the public. Special event used for special purposes such as to increase traffic in your store to increase product sales and to improve your company image within your company or industry". Jadi dapat disimpulkan bahwa memang seringkali event digunakan untuk tujuan khusus seperti untuk melakukan kegiatan promosi atau meningkatkan pengetahuan sebuah produk kepada khalayak ataupun untuk meningktkan citra perusahaan. Jadi bagaimana event juga dirancang sedemikian rupa untuk mengkomunikasikan atau menginformasikan pesan tertentu kepada khalayak sebagai sasaran. Kemampuan sebuah event mempromosikan sebuah produk akhirnya akan berdampak terhadap pemasaran dan pengetahuan khalayak akan produk itu sendiri (Putra \& Smolek, 2020).

\section{g) Teori Manajemen Event Goldblatt}

Seperti yang disebutkan oleh Goldblatt dalam (Pudjiastuti, 2010) terdapat lima tahap yang harus dilakukan untuk menghasilkan special event yang efektif dan efisien yakni, researchatau tahap penelitian. Penelitian ini dilakukan untuk menentukan kebutuhan, keinginan, dan ekspektasi khalayak.Jadi, diharapkan peserta tertarik pada event yang dilakukan dan mengurangi resiko ketidakhadiran.Design, yaitu kegiatan dimana seluruh anggota dikumpulkan untuk mengajukan ide masing-masing yang selanjutnya dihubungkan dan dikonstruksikan menjadi satu filosofi event yang meliputi keuangan, sosial, budaya, dan aspek penting lainnya dalam pelaksanaan sebuah event sehingga dapat menciptakan kesan yang dalam bagi para pengunjung atau tamu undangan. Planning, dilakukan setelah analisis situasi dan bersamaan dengan tahapan design.Tahapan ini penyelenggara event mulai melakukan beberapa hal diantaranya penganggaran waktu yang dipakai, pertimbangan pemilihan tempat (venue), dll.Coordination, merupakan implementasi atau pelaksanaan dari perencanaan yang telah dibuat sebelumnya.Pihak-pihak terkait harus saling berkoordinasi.Seorang manajemen event harus mampu mengoordinasi pihak tersebut agar dapat bekerja secara simultan dengan satu tujuan yakni menghasilkan sebuah event yang sukses.Evaluation, Pada tahap ini event dievaluasi dengan melihat semua proses atau tahapan dari awal sampai dengan selesai event. Evaluasi yang baik akan menghasilkan data dan fakta yang sangat berharga, hususnya untuk mendukung kegiatan yang akan dilakukan p ada masa yang akan datang (Putra \& Smolek, 2020).

\section{Method}

Metode penelitian ini menggunakan metode deskriptif kualitatif dengan menggunakan teori manajemen event milik Goldblatt sebagai pisau analisis untuk menjawab permasalahan yang ada.Teknik pengumpulan data yang digunakan adalah observasi, yakni berupa pengamatan terhadap permasalahan yang sedang diteliti. Selanjutnya dokumentasi, yaitu mencari dokumen-dokumen pendukung seperti foto-foto pada saat pelaksanaan event, keadaan di lapangan, dll.Serta melakukan wawancara kepada pihak-pihak yang dirasa mampu menjawab permasalahan ini. Teknik penentuan informan menggunakan purposive sampling, dimana informan dipilih berdasarkan kriteria yang ditentukan oleh peneliti seperti Founder WartaJazz yakni Bapak Agus Setiawan Basuni, Ibu Farida Nuraini, S.Sos., M.M dan Bapak Franky Andrias Matalata selaku Dinas Pariwisata, Selvia Mita Saraswati sebagai volunteer serta beberapa pengunjung event Reyog Jazz. Pada validitas data peneliti menggunakan teknik triangulasi, dimana dilakukan pengecek kan ulang atau membandingkan suatu informasi yang diperoleh dari sumber yang berbeda. Yakni misalnya membandingkan pengamatan pribadi dengan khalayak atau membandingkan hasil pengamatan dengan wawancara (Fadillah, 2014b).

\section{Results and Discussion}

Berangkat dari banyaknya ungkapan-ungkapan mengenai Kabupaten Ponorogo yang sebenarnya sudah banyak diketahui melalui seni Reyog nya.Tetapi hanya sebatas dikenal namun belum sampai kearah yang diketahui secara mendalam.Dan itu menjadi salah satu alasan pula yang mendasari keinginan memperkenalkan Ponorogo semakin kuat. Maka akhirnya dibuatlah event Reyog Jazz ini sebagai sarana untuk mempromosikan Ponorogo. Event musik Jazz dipilih menjadi salah satu bentuk strategi komunikasi pemasaran budaya dan wisata Kabupaten Ponorogo karena musik Jazz dirasa dapat menjadi jembatan untuk para penikmat musik berkumpul, mengingat musik Jazz 
merupakan musik yang cukup digemari oleh lintas usia. Selain itu dengan culture masyarakat Ponorogo yang cukup tertarik dengan keramaian dan hal baru, dipilih lah event musik. Dari sisi lain event Jazz serupa jika dilihat dari pelaksanaannya event sejenis ini sudah seringkali dilakukan diberbagai daerah, dan itu dapat menarik antusiasme masyarakat. Selain itu juga, sebenarnya event ini lahir ketika adanya pembicaraan atau diskusi antara Bapak Agus Setiawan Basuni sebagai salah satu founder WartaJazz dan juga Bapak Ipong Muchlisoni yang saat itu menjabat sebagai Bupati Ponorogo. Dimana dengan bertemunya mereka dengan kedua background yang mereka geluti, akhirnya terbentuklah sebuah kerjasama antara pemerintah Kabupaten Ponorogo dengan Warta Jazz.Untuk merealisasikan tujuan mengenalkan Ponorogo tersebut dibutuhkan sebuah pengorganisasian yang baik dari awal sampai dengan akhir pelaksanaan event yang disebut manajemen event. Sehingga nantinya akan menghasilkan sebuah event yang berhasil.

\section{1) Manajemen Event}

a) Research

Event Reyog Jazz ini sejak awal dibuat dengan membawa tujuan untuk memperkenalkan ponorogo secara luas. Atau bisa dibilang menjadi jembatan bagi khalayak untuk bisa mengetahui Ponorogo tidak hanya sebatas Reyognya saja, tetapi juga dengan potensi daerahnya. Jadi untuk mewujudkan misi tersebut memang dibutuhkan research atau penelitian sehingga dapat memastikan bagaimana atau langkah apa yang harus diambil pada saat penyusunan konsep. Research yang dilakukan pada event ini berupa survey langsung kepada beberapa orang yang ada diluar Ponorogo mengenai pengetahuan mereka tentang kota Ponorogo. Selanjutnya tim juga melakukan pengamatan terhadap event-event yang pernah dilakukan di Ponorogo, yang nantinya dijadikan sebagai tolak ukur dan juga acuan untuk mencari perbedaan event lain dengan event Reyog Jazz. Selain itu tim juga mencoba melakukan pengamatan terhadap event sejenis yang dilaksanakan di daerah lain, yang nantinya dapat dipelajari kelebihan serta kekurangannya dan dijadikan sebagai media pembelajaran agar nantinya event Reyog Jazz berjalan dengan baik.

\section{b) Design}

Pada tahap ini terjadi sebuah pengkonstruksian hasil research menjadi satu filosofi event yang diinginkan.Seperti Reyog Jazz yang memang memiliki dasar tujuan untuk memperkenalkan Ponorogo. Pada penentuan konsep event, tim memang melakukan sebuah meeting dimana terjadi sebuah brainstorming atau proses penyatuan pikiran-pikiran sehingga akhirnya dapat tercipta sebuah konsep yang unik dan juga fresh. Tahap design diawali dengan penamaan event itu sendiri.Dan selanjutnya di teruskan dengan penentuan tema yang tentunya di sesuaikan dengan kondisi yang ada, dan tercetuslah kalimat Jazz Telaga di Atas Bukit sebagai tema acara.Dan yang terakhir ialah menentukan kemasan acara, dimana tercetus penggabungan unsur budaya Reyog Ponorogo dengan musik jazz yang mana sekaligus menjawab unsur pengenalan potensi budaya dan wisata Ponorogo.

\section{c) Planning}

Untuk event Reyog Jazz, sebagian besar konsep dan perencanaan memang sudah dipikirkan secara matang oleh timWartaJazz dan juga Dinas Pariwisata tentunya. Mulai dari penentuan waktu yang direncanakan satu tahun sebelum pelaksanaan.Karena mempertimbangkan aspek-aspek yang ada seperti waktu bulan purnama, waktu pelaksanaan kesenian Reyog serentak dibeberapa kecamatan di Ponorogo sehingga dapat menambah nilai historical tersendiri pada event Reyog Jazz. Untuk event Reyog Jazz direncanakan akan menjadi event tahunan yang ada di Ponorogo, sehingga pelaksanaannya akan diadakan berkelanjutan. Namun sayangnya pada tahun 2018 event ini sempat tidak terlaksana.Setelah penentuan waktu, tim menentukan tempat pelaksanaan. Disini awalnya tim memiliki dua opsi yakni Alun-Alun dan Telaga Ngebel. Namun akhirnya dipilih Telaga Ngebel karena selain memperhatikan efek berkelanjutan di sektor pariwisata juga mempertimbangan komoditas lainnya seperti penginapan.Karena memang tamu dan pengunjung yang datang tidak hanya berasal dari Ponorogo.yang ketiga adalah penentuan pengisi acara. Untuk menentukan pengisi acara, Warta Jazz meiliki formula tersendiri yakni mempertimbangkan crowd caller, memperhatikan komponen unsur Jazz nya, tidak melupakan musisi-musisi atau kelompok Jazz lokal, mencoba untuk memasukkan line up musisi internasional. Selanjutnya untuk budget disini anggaran sepenuhnya berasal dari APBD Ponorogo meskipun tetap ditambah dengan beberapa sponsor. Dan yang terakhir ialah menentukan layanan pendukung, yakni dengan caracommunity development dan juga capacity building yang tentunya melibatkan masarakat lokal Ponorogo. 


\section{d) Coordination}

Tahap coordination merupakan wujud implementasi atau pelaksanaan dari perencanaan yang sudah dibuat sebelumnya. Wujud dari perencanaan yang telah dibuat yaitu dimulai dengan dilakukannya press conference. Selanjutnya adanya kegiatan bersih-bersih Telaga Ngebel, lalu acara hiburan oleh komunitas Jazztilan Ponorogo, dan juga workshop musik road to Reyog Jazz, dan yang terakhir ialah pelaksanaan event Reyog Jazz Ponorogo.yang mana dalam pelaksanaannya dibutuhkan koordinasi yang baik antar tim. Untuk panitia sendiri dibagi menjadi beberapa cluster, yang mana mereka akan bekerja sesuai dengan tanggung jawabnya masing-masing dan menghindari mis komunikasi. Komunikasi juga selalu dijaga, dengan menggunakan bantuan HT (Fadillah, Zhenglin, \& Hao, 2019).

\section{e) Evaluation}

Evaluasi dilakukan untuk dijadikan tolak ukur berhasil atau tidaknya sebuahevent. Selain itu juga tentunya dapat dijadikan acuan untuk event selanjutnya. Disini tim Reyog Jazz melakukan evaluasi baik pada saat event berlangsung dan juga setelah event berlangsung. Jadi untuk beberapa hal teknis yang bisa dikoreksi langung, maka tim akan melakukan evaluasi saat itu juga. Bentuk paling umum dari evaluasi acara adalah dilihat pada saat acara itu berakhir, dan dapat dilakukan melalui beberapa cara salah satunya ialah melalui survey tertulis.Setelah dilakukan survey tertulis, pengunjung rata-rata menilai jika event Reyog Jazz ini menarik, meskipun dengan beberapa alasan yang berbeda satu sama lain. Ada yang mengatakan karena konsep penyatuan musik modern dan juga budaya tradisional, ada pula yang tertarik dengan pengisi acara, dan juga dianggap melalui event ini dapat mengumpulkan penikmat musik dari beberapa generasi.Selain menarik, mereka juga menilai bahwa event Reyog Jazz ini tidak hanya sekedar sebagai acara hiburan. Tetapi berhasil memasukkan tujuan lain yakni sebagai bagian dari strategi promosi, karena memang dengan event besar seperti ini bisa mendatangkan wisatawan, mengenalkan wisata khususnya Telaga Ngebel sebagai salah satu pariwisata Ponorogo dan juga seni Reyog khas Ponorogo. Dilihat dari sisi lain yakni dari Tim Reyog Jazz, tentunya mereka menilai bahwa event ini sudah dikatakan cukup berhasil. Itu mereka katakan dengan tingkat antusiasme masyarakat yang tinggi, yakni adanya peningkatan dari diadakannya event pertama dan kedua.Namun tidak hanya beberapa keberhasilan yang telah disampaikan tadi, terdapat beberapa koreksi juga yang disampaikan oleh pengunjung.Yakni terkait dengan sistematika pelaksanaan event, pengunjung berpendapat bahwa harus lebih dipertegas dan diperbaiki mulai dari pintu masuk, kemudian area penonton yang seharusnya diberikan pembatas yang jelas, serta ketertiban di sekitar area tempat pelaksanaan.Selain itu mengenai konsep panggung yang kurang luas, serta keinginan audiens apabila tempat pelaksanaan di gilir sehingga tidak hanya dilakukan di Telaga Ngebel (Jandevi, 2019b).

Sebagai timevent yang cukup berpengalaman, WartaJazz juga tetap mengalami beberapa kesulitan saat melakukan manajemen event, terkait dengan kerjasama dengan masyarakat Ponorogo. Terkadang apa yang menjadi keinginan tim event tidak terlalu di support oleh masyarakatnya. Seperti pengadaan stand makanan minuman, pada event Reyog Jazz pertama stand sudah disediakan namun dukungan masyarakat sangat kurang, sebab pada saat itu sangat sedikit sekali yang mau mengisi stand tersebut untuk berjualan. Selain itu karena letak Telaga Ngebel yang cukup jauh dengan area kota, maka cukup menyulitkan tim jika butuh sesuatu yang urgent. Sehingga itu diatasi dengan meminta bantuan seseorang yang sedang ada di area kota.

2) Aktivitas Publikasi pada Event Reyog Jazz.

Aktivitas yang dilakukan sebagai wujud publikasi event Reyog Jazz terletak pada :

a) Press Conference

Press Conference dilakukan sebelum acara atau perhelatan dilangsungkan.Press conference event. Dimana kegiatan tersebut dihadiri oleh para tim dari Reyog Jazz, tim event yakni WartaJazz, Pemerintah, beberapa pengisi acara, dan tentunya media.

\section{b) Kerjasama Media}

Media yang digunakan untuk mempromosikan event ini tidak hanya dilakukan melalui sosial media yang dapat diakses dengan mudah oleh masyarakat.Namun disini tim Reyog Jazz melakukan kerjasama media baik lokal ataupun internasional yang mana secara tidak langsung berita tentang 
Reyog Jazz Ponorogo akan tersebar secara cepat.. Bentuk media disini yakni berupa radio, e-news paper, berita online, dan juga liputan televisi

c) Media luar ruangan

Selain menyebarkan iklan pada social media, disini event Reyog Jazz juga menyebarkan informasi melalui spanduk, baliho, dan billboard yang mereka pasang pada tempat-tempat umum, jalan raya atau pusat perbelanjaan, dengan maksud menarik perhatian masyarakat lebih banyak lagi yang nantinya diharapkan agar menambah daftar kunjungan event Reyog Jazz.

\section{3) Efek Komunikasi}

a) Efek Kognitif

Efek ini ditimbul dengan adanya bantuan media massa sebagai perantara. Dimana ini dilakukan pada saat publikasi event Reyog Jazz.Dimana publikasi event ini memanfaatkan media sosial, media cetak, dan juga elektronik.Sehingga dengan itu masyarakat yang semula tidak mengetahui event ini menjadi tahu.Karena tidak dapat dipungkiri saat ini media menjadi sumber utama seseorang mendapatkan informasi.Seperti yang sudah diamati peneliti, rata-rata pengunjung mengetahui event ini melalui media sosial.

\section{b) Efek Afektif}

Efek ini memiliki kadar lebih tinggi dibandingkan efek kognitif. Karena pada tahap ini perasaan seseorang sudah mulai digunakan. Dengan adanya publikasi diatas, maka mau tidak mau seseorang akan mengetahui informasi lebih dalam lagi. Dimana seseorang akan mencari tahu informasi selanjutnya.. Dengan sudah dipaparkannya list bintang tamu, konsep singkat maka akan timbul perasaan penasaran kepada calon pengunjung event Reyog Jazz.

\section{c) Efek Konatif atau Behavioral}

Dimana pada tahap ini merupakan efek yang timbul pada diri seseorang terkait dengan tingkah laku.Pada event ini, puncak dari efek konatif ialah ketika seseorang sudah rela dan tertarik mengunjungi event Reyog Jazz dengan beberapa hal yang sudah disampaikan pada saat publikasi.Efek ini timbul bisa karena ketertarikan seseorang dengan konsep yang disampaikan ataupun dengan bintang tamu yang disuguhkan.Pada penelitian ini pengunjung yang datang rata-rata tertarik dengan konsep penyatuan musik Jazz dan Reyog.Dimana mereka menganggap penyatuan tersebut sangat menarik dan unik serta belum pernah mereka temukan sebelumnya.

\section{Conclusion}

Setelah adanya interpretasi analisa pembahasan tadi maka diperoleh kesimpulan bahwa tim Reyog Jazz menerapkan manajemen event dengan cukup baik. Mereka melakukan runtutan-runtutan manajemen event mulai dari research sampai dengan evaluating. Konsep penyatuan budaya Reyog Ponorogo dan musik Jazz juga bisa dikatakan berhasil melekat di masyarakat dan juga beberapa media dengan banyaknya ungkapan ketika Jazz bertemu Reyog di lereng wilis. Namun pada beberapa point seperti pada saat planning penetapan waktu yang dikatakan event ini akan dijadikan event tahunan, nyatanya pada tahun 2018 sempat tidak terlaksana. Selain itu pada point evaluasi terdapat beberapa koreksi terkait sistematika pelaksanaan event.Disampaikan bahwa ketertiban di sekitar area pelaksanaan event harus diperhatikan dan terkait tata letak audiens yang dikatakan tidak adanya pembatas yang jelas.Begitupun juga dengan kenaikan kunjungan wisata.Memang terjadi kenaikan yang signifikan setiap bulan terkait kunjungan wisata khususnya di Telaga Ngebel.Namun kenaikan tersebut terdapat pada wisatawan nusantara, sedangkan pada wisatawan mancanegara belum bisa mengimbangi kenaikan dari wisatawan nusantara.

Berdasarkan hasil kesimpulan di atas, peneliti berharap semoga dapat memberikan manfaat baik secara praktis maupun teoritis. Hasil penelitan ini memang masih sangat jauh dari kesempuraan, akan tetapi berdasarkan hasil penelitian ini, maka peneliti memberikan saran yang diharapkan dapat dijadikan sebagai bahan pertimbangan yakni sebagai berikut:

1. Terkait dengan planning atau rencana Reyog Jazz sebagai event tahunan milik Ponorogo, seharusnya terlepas dari alasan teknis yang ada diharapkan untuk konsisten, yakni dengan dilaksanakannya event ini setiap tahun. Sehingga nantinya animo masyarakat terhadap event ini akan tetap terjaga. 
2. Penerapan konsep Reyog di panggung Reyog Jazz bisa lebih dimunculkan dan juga diperkuat. Jadi tidak hanya pada saat pelaksanan namun bisa diletakkan sebagai icon panggung, sebab itu nantinya akan menjadi identitas yang melekat dan dimiliki event Reyog Jazz dari tahun ke tahun.

3. Terkait dengan sistematika pelaksanaan, supaya dipertegas dan diberikan batasan yang jelas dari mulai awal pintu masuk sampai dengan area penonton. Sehingga nantinya pengunjung akan merasa nyaman pada saat event berlangsung.

4. Melakukan promosi event Reyog Jazz secara lebih luas diharapkan mampu menaikkan kunjungan wisatawan mancanegara, sehingga tidak kalah dengan kenaikan yang cukup signifikan dari wisatawan nusantaranya.

\section{References}

Any, N. (2009). Manajemen Event. Bandung: Alfabeta.

Effendy, O. U. (2007). Ilmu,Teori, dailsafat Komunikasi. Bandung: PT. Citra Aditya Bakti.

Hedynata, M. L., \& Radianto, W. E. (2016). Strategi Promosi Dalam Meningkatkan Penjualan Luscious Chocolate Potato Snack. Jurnal Manajemen dan Star Up Bisnis, 87-96.

Kriyantono, R. (2012). Teknik Praktis Riset Komunikasi : Disertai Contoh Praktis Riset Media, Public Relations, Advertising, Komunikasi Organisasi, Komunikasi Pemasaran. Jakarta: Kencana Prenada Media Grup.

Ndraha, T. (2005). Teori Budaya Organisasi. Jakarta: PT Rineka Cipta.

Prayogi, R., \& Danial, E. (2016). Pergeseran Nilai-Nilai Budaya Pada Suku Bonai Sebagai Civic Culture Di Kecamatan Bonai Darussalam Kabupaten Rokan Hulu Provinsi Riau. Jurnal Humanika, 61-79.

Prisgunanto, I. (2006). Komunikasi Pemasaran: Strategi dan Taktik. Bogor: GhaliaIndonesia.

Pudjiastuti, W. (2010). Special Event. Jakarta: PT Elex Media Komputindo.

Fadillah, D. (2014a). Strategi komunikasi pembentukan budaya organisasi. Humanika, 14(1). https://doi.org/https://doi.org/10.21831/hum.v14i1.3327

Fadillah, D. (2014b). STRATEGI KOMUNIKASI PENINGKATAN PARTISIPASI POLITIK KADER PEREMPUAN PARTAI AMANAT NASIONAL KABUPATEN SLEMAN DALAM PEMILU LEGISLATIF 2014. Universitas Gadjah Mada.

Fadillah, D., Zhenglin, L., \& Hao, D. (2019). Social Media and General Elections in Malaysia 2018 and Indonesia 2019. Jurnal Komunikasi ISKI, 4(1), 1-8. https://doi.org/10.25008/jkiski.v4i1.255

Jandevi, U. (2019a). Communication strategy to improve women's political participation in Indonesia. International Journal of Communication and Society, 1(2), 68-81. https://doi.org/10.31763/ijcs.v1i2.46

Jandevi, U. (2019b). New media for increasing political participation in Indonesia. International Journal of Communication and Society, 1(1), 1-8. https://doi.org/10.31763/ijcs.v1i1.19

Lotan, F. F. (2019). Making a positive internet through Socmed Agawe Guyub. International Journal of Communication and Society, 1(1), 9-16. https://doi.org/10.31763/ijcs.v1i1.22

Nurislamia, F., \& Asriya, E. S. (2019). International communication dynamics of American intervention efforts to democratize in the arab spring through forward strategy for freedom in the middle east. International Journal of Communication and Society, 1(2), 82-88. https://doi.org/10.31763/ijcs.v1i2.37

Putra, F. D., \& Smolek, S. (2020). Peace language and conflict resolution in harmony communication. International Journal of Communication and Society, 2(2), 86-93. https://doi.org/10.31763/ijcs.v2i2.134

Fatika Bella Ayunda (Analisis manajemen event Reyog Jazz sebagai salah satu strategi komunikasi pemasaran budaya dan wisata Kabupaten Ponorogo) 
Sintawati, W. (2019). Computer mediated communication for construction-supported constructivism in communication and cultural learning. International Journal of Communication and Society, 1(1), 34-42. https://doi.org/http://dx.doi.org/10.31763/ijcs.v1i1.29

Soedarso, Nurif, M., \& Windiani. (2014). Potensi dan Kendala Pengembangan Pariwisata Berbasis Kekayaan Alam dengan Pendekatan Marketing Places (Studi Pengembangan Pariwisata Kabupaten Bojonegoro). Jurnal Sosial Humaniora, 136-149.

Tjiptono, F. (2001). Strategi Pemasaran Edisi Ketiga Cetakan Pertama. Yogyakarta: Andi Offset. 